\title{
IMPLEMENTATION OF THE DIGITAL GREEN CERTIFICATE (COVID PASSPORT) AS A KEY ICT PROJECT IN THE EUROPEAN UNION - A SCIENTIFIC COMMENT
}

\author{
Jakub Kubiczek
}

Department of Economic and Financial Analysis, University of Economics in Katowice, ul. 1 Maja 50, 40-287

Katowice, Poland.

Email: jakub.kubiczek@edu.uekat.pl

Article History: Received on $16^{\text {th }}$ June 2021, Revised on $29^{\text {th }}$ June 2021, Published on $7^{\text {th }}$ July 2021

\begin{abstract}
The outbreak of the COVID-19 pandemic and the closure of the borders have slowed down progressive internationalization. Travel not only consists of tourist trips but also business trips. This comment emphasizes the necessity to implement The Digital Green Certificate (Covid passport) and presents the process of its implementation as a complex project on an international scale. The considerations summarize that the implementation of the Covid passport will be successful when the negative impact the pandemic has on travel is eliminated and the number of travelers returns to the level before the restrictions were introduced.
\end{abstract}

Keywords: Covid-19, Travel, Covid Passport, ICT Project.

\section{INTRODUCTION}

Globalization created an international business environment. The outbreak of a COVID-19 pandemic has impacted the existing products and services (Obradović et al., 2020). Governments have closed their national borders to contain the spread of the COVID-19 pandemic. This translated into a slowdown or even a halt to the processes of internationalization. The full reopening of borders and the restoration of passenger traffic has become one of the key challenges in the international arena.

The study is a challenge/perspective paper and a scientific commentary on the implementation of The Digital Green Certificate (Covid passport) as a key ICT project in the European Union. The considerations presented in this paper combine both practical and theoretical aspects, and the whole dilatation is embedded in a scientific discussion.

\section{THE DIGITAL GREEN CERTIFICATE (COVID PASSPORT)}

The initial step was the introduction of quarantine obligation and a requirement to have a negative RT-PCR test result performed before crossing the border. Then, following the invention of the vaccine, several countries announced the lifting of the test requirement and the quarantine requirement for those vaccinated with a full dose. However, the legal regulations took place at the level of a given state, and not at the scale of international agreements.

The first initiative towards harmonization of regulations in the field of international travel conditions was launched within the European Union on 17/03/2021. The European Commission (2021) announced that it has started the project to create The Digital Green Certificate, commonly known as the Covid passport. It should be noted that the coordination of the project by the European Commission will ensure the unification of regulations and thus, equal something very important when it comes to ethics - the treatment of tourists (Kubiczek, 2020).

Since even a similar document has never been introduced before, it can be treated as an innovation. Innovations in Information and Communication Technologies (ICT) offer wide opportunities that increase the number of public sector services provided by governments (Irani et al. 2007). The outbreak of the COVID-19 pandemic has created many affairs related to the implementation of ICT in public administration (Kubiczek and Hadasik, 2021). Nonetheless, the creation of the Covid passport and its implementation will allow us to take a step towards digitizing public administration. The use of technology is a key process in adapting public administration to the realities of the digital economy (RodríguezBolívar, 2014 p. IX).

The creation and introduction of the Digital Green Certificate can be treated as an international project in the field of ICT. Project Management, especially within Information and Communication Technologies, is an essential part of today's world because it has a practical aspect that is perceived by society (Morcov et al. 2020). Although implementation is an important step in facilitating mobility, it creates many risks and uncertainties. Same for other initiatives related to ICT implementation in public administration (Rodríguez-Bolívar, 2014 p. IX).

Nonetheless, The European Commission has announced that by 1/07/2021 at the latest, all EU countries will honor this document. Every EU citizen will be able to obtain it for free if recovered from COVID-19, received a negative test result, or been vaccinated against COVID-19. It should be emphasized that the Covid passport will have several important features (European Commission, 2021). First of all, it is worth noting that it will have a dual form. This means 
that its digital version will be equivalent to the paper version. The passport will be available for free in the national language and in English. All EU countries will be obliged to recognize it.

The Digital Green Certificate will contain a QR code with a digital signature which is to ensure greater protection against its counterfeiting. When checking The Digital Green Certificate, the border guard checks the QR code and the signature is verified.

It is worth noting that each issuing body has its digital signature key which will be a confirmation of credibility. Instead of a single, international database, the data on passport holders will be scattered among the countries that issued the document. However, thanks to the gateway created and supervised by the European Commission, passports can be verified across the EU.

\section{IMPLEMENTATION OF THE DIGITAL GREEN CERTIFICATE (COVID PASSPORT) - AN INTERNATIONAL PROJECT}

The European Commission also undertakes to support implementation in the field of legal alignment and development of software. It should be noted that there is no single definition of success in project management (Pankratz and Basten, 2018). Nonetheless, it is assumed that efficient coordination of international projects is crucial in achieving success which depends on achieving efficiency in three dimensions: cost, time, and quality (Atkinson, 1999).

The price of a given project is influenced by, inter alia, its complexity (comprehensiveness). It should be noted that the introduction of The Digital Green Certificate is an international project in which all EU countries participate. Moreover, the speed of its implementation is extremely important as it will enable more efficient movement within the European Union. Consequently, the size of the project in question requires a high budget. It should be noted that the European Union countries allocated enormous resources to create a technological infrastructure that provides wide access to the Internet (Archmann and Iglesias, 2010).

When it comes to the implementation of the Covid passport, the time dimension is crucial -there were only a few months between the announcement of the start of the project and the start of the tourist season. Restrictions on the movement of people are particularly acute for economies that rely on tourism. Moreover, protracted restrictions on free movement and reduced demand for travel affect not only countries but also all tourism enterprises (Hadasik and Kubiczek, 2020).

The quality of the considered project can be equated with the efficiency of the administration systems in a given country (Oyerinde and Bankole, 2019). One of the factors it is influenced by is the level of technological infrastructure development in a country. If it is in a bad condition or underdeveloped, it may be a problem to implement ICT within the public administration (Asogwa, 2013; Jorge-Pagán et al., 2020).

Implementation of the digital services is determined by the availability of the Internet, as well as the speed and stability of the connection. The level of technological development and infrastructure in the European Union countries is high, and the administration in the countries is so digitized that it does not constitute an obstacle to the introduction of software. It should be emphasized that, although the European Commission coordinates the course of the Covid passport project, the efficiency of its adaptation depends on the given country.

Considering success in terms of cost, time, and quality can also be reduced to the overall effectiveness of the project, understood as total as "the maximization of output for a given level of resources; the effectiveness directed to the achievement of goals or objectives" (Belout, 1998; Iriarte and Bayona, 2020). The effectiveness of the implementation of ICT projects in the public can be assessed by the stakeholders themselves.

Implementation of The Digital Green Certificate also generates a few challenges. The initiative itself, although it is carried out in the European Union, is international. Therefore, integration of many IT systems is required in such a way that when countries issue the certificate, other countries accept it. Furthermore, some countries have implemented earlier than others, which causes some confusion among travelers and requires each of them to check beforehand what entry regulations a given country has. It is also known that although the European Commission wanted The Digital Green Certificate to operate from July 1, many countries have not introduced it by that day.

\section{CONCLUSION}

The European Union initiative is to make travel easy again, and the need to test and translate the test result will not increase the cost of the trip. Thus, the number of travelers should return to the level before the restrictions were introduced. Therefore, the implementation of the Covid passport will be successful when the negative impact the pandemic has on travel is eliminated. It should be remembered that it is essential that all EU countries respect The Digital Green Certificate.

\section{REFERENCES}

1. Archmann, S., \& Iglesias, C. (2010). eGovernment: A driving force for innovation and efficiency in public administration. EIPA Scope, 2010(1), 29-36. 
2. Asogwa, B. E. (2013). Electronic government as a paradigm shift for efficient public services. Library Hi Tech, 31(1), 141-159. https://doi.org/10.1108/07378831311303985

3. Atkinson, R. (1999). Project management: cost, time, and quality, two best guesses and a phenomenon, its time to accept other success criteria. International Journal of Project Management, 17(6), 337-342. https://doi.org/10.10 16/s0263-7863(98)00069-6

4. Belout, A. (1998). Effects of human resource management on project effectiveness and success: toward a new conceptual framework. International Journal of Project Management, 16(1), 21-26. https://doi.org/10.1016/S026 3-7863(97)00011-2

5. European Commission (2021). COVID-19: Digital green certificates. https://ec.europa.eu/info/live-work-traveleu/coronavirus-response/safe-covid-19-vaccines-europeans/covid-19-digital-green-certificates en

6. Hadasik, B., \& Kubiczek, J. (2020). Economic determinants of the tourist enterprises' activities during the trend of independent tourist trips organization by travelers. In Znaczenie ekonomii we współczesnym świecie (pp. 5579), Wydawnictwo Naukowe ArchaeGraph.

7. Irani, Z., Love, P. E. D., \& Montazemi, A. (2007). e-Government: past, present, and future. European Journal of Information Systems, 16(2), 103-105. https://doi.org/10.1057/palgrave.ejis.3000678

8. Iriarte, C., \& Bayona, S. (2020). IT projects success factors: a literature review. SciKA-Association for Promotion and Dissemination of Scientific Knowledge. International Journal of Information Systems and Project Management, 8(2), 49-78.

9. Jorge-Pagán, J., Ojeda-Castro, A. M., Valera-Márquez, J., \& González, M. A. (2020). Essentials issues for egovernment efficiency. Issues in Information Systems, 21(1), 98-104. https://doi.org/10.48009/1_iis_2020_98104

10. Kubiczek, J. (2020). Etyka i społeczna odpowiedzialność biznesu na przykładzie linii lotniczych. Marketing $i$ Rynek, 2020(10), 23-29. https://doi.org/10.33226/1231-7853.2020.10.3

11. Kubiczek, J., \& Hadasik, B. (2021). Challenges in reporting COVID-19 daily cases and presenting them to society. Journal of Data and Information Quality (accepted). http://dx.doi.org/10.1145/3470851

12. Morcov, S., \& Pintelonv, L. (2020). Definitions, characteristics, and measures of IT Project Complexity - a Systematic Literature Review (JB). International Journal of Information Systems and Project Management, 8, 5-21. https://doi.org/10.12821/ijispm080201

13. Obradović, M., Kljajić, M., Obradović, A., \& Pavićević, M. (2020). E-Services: Efficiency and Use in Modern Business. Proceedings of the International Scientific Conference - Sinteza 2020. https://doi.org/10.15308/sinteza-2020-128-133

14. Oyerinde, Y., \& Bankole, F. (2019). Measuring Efficiency and Productivity of ICT Infrastructure Utilization. UKAIS2019 Proceedings.

15. Pankratz, O., \& Basten, D. (2018). Opening the black box: Managers' perceptions of IS project success mechanisms. Information \& Management, 55(3), 381-395. https://doi.org/10.1016/j.im.2017.09.005

16. Rodríguez-Bolívar, M. P. (2014). Measuring E-government efficiency. Springer, New York, 2014. 